\title{
Dysregulation of Hypoxia-Inducible Factor by Presenilin/ $\gamma$-Secretase Loss-of-Function Mutations
}

\author{
Muriel R. Kaufmann, ${ }^{1}$ Sandra Barth, ${ }^{1}$ Uwe Konietzko, ${ }^{2}$ Bei Wu, ${ }^{3}$ Sascha Egger, ${ }^{1}$ Reiner Kunze, ${ }^{4}$ Hugo H. Marti, ${ }^{4}$ \\ Meike Hick, ${ }^{5}$ Ulrike Müller, ${ }^{5}$ Gieri Camenisch, ${ }^{1}$ and Roland H. Wenger ${ }^{1}$ \\ ${ }^{1}$ Institute of Physiology and Zürich Center for Integrative Human Physiology, University of Zürich, CH-8057 Zürich, Switzerland, ${ }^{2}$ Division of Psychiatry \\ Research, University of Zürich, CH-8008 Zürich, Switzerland, ${ }^{3}$ Center for Neurologic Disease, Harvard Medical School, Boston, Massachusetts 02115, and \\ ${ }^{4}$ Institute of Physiology and Pathophysiology and ${ }^{5}$ Department of Pharmacy and Molecular Biotechnology, University of Heidelberg, D-69120 Heidelberg, \\ Germany
}

Presenilin (PSEN) 1 and 2 are the catalytic components of the $\gamma$-secretase complex, which cleaves a variety of proteins, including the amyloid precursor protein (APP). Proteolysis of APP leads to the formation of the APP intracellular domain (AICD) and amyloid $\beta$ that is crucially involved in the pathogenesis of Alzheimer's disease. Prolyl-4-hydroxylase-domain (PHD) proteins regulate the hypoxiainducible factors (HIFs), the master regulators of the hypoxic response. We previously identified the FK506 binding protein 38 (FKBP38) as a negative regulator of PHD2. Genetic ablation of PSEN1/2 has been shown to increase FKBP38 protein levels. Therefore, we investigated the role of PSEN1/2 in the oxygen sensing pathway using a variety of genetically modified cell and mouse lines. Increased FKBP38 protein levels and decreased PHD2 protein levels were found in PSEN1/2-deficient mouse embryonic fibroblasts and in the cortex of forebrain-specific PSEN1/2 conditional double knock-out mice. Hypoxic HIF- $1 \alpha$ protein accumulation and transcriptional activity were decreased, despite reduced PHD2 protein levels. Proteolytic $\gamma$-secretase function of PSEN1/2 was needed for proper HIF activation. Intriguingly, PSEN1/2 mutations identified in Alzheimer patients differentially affected the hypoxic response, involving the generation of AICD. Together, our results suggest a direct role for PSEN in the regulation of the oxygen sensing pathway via the APP/AICD cleavage cascade.

\section{Introduction}

Hypoxia is a characteristic feature of many neurodegenerative disorders, such as familial Alzheimer's disease (FAD) or Parkinson's disease (PD) (reviewed by Ogunshola and Antoniou, 2009). The central regulators of the response to low oxygen partial pressures are the hypoxia-inducible factors (HIFs) (Wenger et al., 2005; Semenza, 2007). Under normoxic conditions, a family of prolyl-4-hydroxylase domain (PHD) proteins hydroxylate the HIF $\alpha$ subunits, tagging them for ubiquitin-mediated proteasomal degradation (Maxwell et al., 1999; Bruick and McKnight, 2001). In hypoxia, the activity of PHDs decreases, resulting in the stabilization and accumulation of $\mathrm{HIF} \alpha$ subunits that translocate to the nucleus and heterodimerize with their constitutive counterpart HIF-1 $\beta$ /aryl hydrocarbon receptor nuclear translocator

Received July 17, 2012; revised Nov. 21, 2012; accepted Dec. 1, 2012.

Author contributions: M.R.K., G.C., and R.H.W. designed research; M.R.K., S.B., and B.W. performed research; U.K., S.E., R.K., H.H.M., M.H., and U.M. contributed unpublished reagents/analytic tools; M.R.K., S.B., U.K., H.H.M., G.C., and R.H.W. analyzed data; M.R.K. and R.H.W. wrote the paper.

This work was supported by the Swiss National Science Foundation (Grant 31003A_129962/1 to R.H.W.; Grant 31003A_130148 to U.K.), the Ministry of Science, Research and Arts of Baden-Württemberg (Grant 23-7532.22-2012/1 to H.H.M.), and the German Research Foundation (Grants MU1457/8-1 and MU1457-9-1 to U.M.). We thank B. de Strooper, C.0. Joe, and R.M. Nitsch for the generous gifts of plasmids and cell lines; P. Spielmann for expert technical help; and D. Hoogewijs for helpful discussions.

The authors declare no competing financial interests.

Correspondence should be addressed to Dr. Roland H. Wenger, Institute of Physiology, University of Zürich, Winterthurerstrasse 190, CH-8057 Zürich, Switzerland. E-mail: roland.wenger@access.uzh.ch.

S. Barth's present address: YES Pharmaceutical Development Services GmbH, D-61381 Friedrichsdorf, Germany. DOI:10.1523/JNEUROSCI.3402-12.2013

Copyright $\odot 2013$ the authors $\quad 0270-6474 / 13 / 331915-12 \$ 15.00 / 0$
(ARNT) (Schofield and Ratcliffe, 2004; Kaelin and Ratcliffe, 2008). The now active HIF complexes regulate genes that are involved in hypoxic adaptation, including glucose metabolism, angiogenesis, and neurodegeneration. The transcriptional activity of HIF is further regulated by factor inhibiting HIF (FIH) that hydroxylates a distinct asparagine residue in the carboxyterminal region of HIF- $\alpha$, attenuating HIF transcriptional activity (Mahon et al., 2001; Lando et al., 2002).

Recently, we reported that the peptidyl-prolyl cis/trans isomerase FKBP38 specifically interacts with PHD2 and negatively regulates its stability (Barth et al., 2007; Barth et al., 2009). FKBP38 has been shown previously to interact with presenilin (PSEN) 1 and 2 which antagonizes its antiapoptotic function (Wang et al., 2005). PSEN 1 and 2 form the catalytic core of the $\gamma$-secretase complex (De Strooper et al., 1998; Wolfe et al., 1999). This complex cleaves many type I membrane proteins, such as amyloid precursor protein (APP) (De Strooper et al., 1998) or Notch (De Strooper et al., 1999). PSEN1 and PSEN2 have been discovered through their genetic linkage to FAD (Sherrington et al., 1995). Despite thorough research, the underlying pathologic processes causing AD remain elusive. However, tissue hypoxia and hypoperfusion have been linked to the pathological progression of FAD (Ogunshola and Antoniou, 2009; Zhang and Le, 2010). Vascular ischemia/hypoxia increase APP expression and the production of A $\beta$ (Kalaria et al., 1993; Webster et al., 2002; Li et al., 2009) as well as the amyloidogenic $\beta$-secretase BACE1 (Sun et al., 2006; Zhang et al., 2007), suggesting that oxygen signaling is also involved in the progression of $\mathrm{AD}$. 
The finding that PSEN1/2-deficient mouse embryonic fibroblasts (MEFs) have higher FKBP38 protein levels (Wang et al., 2005) led us to hypothesize that presenilins could be involved in the regulation of the oxygen signaling pathway. To explore a putative role of PSEN1/2 in PHD/HIF regulation, we analyzed wild-type (wt), PSEN1, and PSEN2 single knock-out (ko) as well as PSEN1/2 double-ko MEFs (Herreman et al., 1999; 2003). We confirmed that MEF cells lacking PSEN1/2 have increased constitutive FKBP38 protein levels causing decreased PHD2 protein levels. In addition, we found that the lack of PSEN1/2 leads to an attenuated hypoxic response that in turn results in a decreased feedback regulation of PHD2 transcript levels. The observed effects were dependent on the generation of the APP intracellular domain (AICD) but not on the Notch cleavage cascade.

\section{Materials and Methods}

Plasmid generation and lentiviral transduction. psG5-mPSEN1 and pcDNA3.1-mPSEN2 expression plasmids were kind gifts of B. de Strooper (Leuven, Belgium). The pUKBK-citAICD expression vector was described previously (Goodger et al., 2009). PSEN and citAICD Entry vectors were generated by cloning PCR fragments into the NcoI/XhoI (for mPSEN1) or EcoRI/XhoI (for mPSEN2) sites of pENTR4 (Invitrogen). Cloning of pLenti-mPSEN and G4-DBD-PSEN1 constructs was performed using Gateway technology (Invitrogen). The inserts of the Entry vectors were verified by sequencing (Microsynth). Viral particles were produced in HEK293T human embryonic kidney cells using the ViraPower lentiviral expression system according to the manufacturer's protocol (Invitrogen).

Cell culture and transient transfections. PSEN wt, PSEN1 ko, and PSEN1/2 ko, as well as MEFs containing wt human PSEN1 or clinically relevant mutations of PSEN1 ( $\Delta \mathrm{E} 9, \mathrm{~A} 246 \mathrm{E}, \mathrm{L} 166 \mathrm{P})$ or PSEN2 (N141I), were kindly provided by de Strooper (Herreman et al., 1999; 2003; Bentahir et al., 2006). The HeLa cervix carcinoma cell line HeLa/trTAA/TREN1-ICD, capable of doxycycline-induced expression of human Notch1-IC (Lee et al., 2009), was a kind gift from C. O. Joe (South Korea). APP ko MEFs and APP/APPLP2 ko MEFs were derived from the corresponding ko mice (Zheng et al., 1995; von Koch et al., 1997). All cells were grown in high-glucose DMEM (Sigma), and Notch1-IC expression was induced by $1 \mu \mathrm{g} / \mathrm{ml}$ doxycycline (Sigma). The HEK293citAICD cells were described previously (von Rotz et al., 2004). Expression of citAICD was induced with $1 \mu \mathrm{M}$ tebufenozide for $24 \mathrm{~h}$. For hypoxic exposure, cells were grown in a gas-controlled glove box (InvivO $_{2} 400$, Ruskinn Technologies). Transient transfections of MEFs were performed using Lipofectamine2000 (Invitrogen). HeLa cells were transiently transfected using the polyethylenimine (Polysciences) method as described previously (Stiehl et al., 2006). The specific $\gamma$-secretase inhibitor $\mathrm{N}$-[N-(3,5-difluorophenacetyl)-L-alanyl]-S-phenylglycine $t$-butyl ester (DAPT) was purchased from Sigma.

Immunoblotting. Immunoblotting was performed as described previously (Martin et al., 2005). Primary antibodies used were rabbit antiAPP, C-terminal (Sigma A8717), rabbit anti-human PHD2 (Novus Biologicals), rabbit anti-mouse PHD2 (Novus Biologicals), rabbit antiFKBP38 (Edlich et al., 2005), rabbit anti-HIF-1 $\alpha$ (Novus Biologicals), mouse anti-N-cadherin (BD Biosciences), mouse anti- $\beta$-actin (Sigma). Horseradish peroxidase-coupled secondary anti-mouse and anti-rabbit antibodies were purchased from Pierce. Chemiluminescence detection was performed using Supersignal West Dura (Pierce), and signals were recorded with a charge-coupled device camera (Lightimager LAS4000mini, Fujifilm).

Reporter genes and mammalian two hybrid assays. Cloning of the HIFdependent firefly luciferase reporter gene $\mathrm{pH} 3 \mathrm{SVL}$ and the $885 \mathrm{bp}$ mouse Hifla promoter constructs were described previously (Wenger et al., 1997; 1998; Wanner et al., 2000). Cells were cotransfected with $1 \mu \mathrm{g}$ of pH3SVL and 20 ng of pRLSV40 Renilla luciferase reporter vector (Promega). Cells were harvested in passive lysis buffer (Promega), and luciferase reporter gene activity was determined using the dual-luciferase reporter system according to the manufacturer's instructions (Promega).
Mammalian two-hybrid analysis was performed using the mammalian Matchmaker system (Clontech, BD Biosciences) as previously described (Barth et al., 2007).

Animal experimentation. Male C57BL/6 mice were maintained at the animal facility of the University of Heidelberg, Heidelberg, Germany. All animal procedures were approved by the animal welfare committee (Regierungspräsidium Karlsruhe, Karlsruhe, Germany). Hypoxia was induced in adult mice by substituting nitrogen for oxygen using a Digamix 5SA 18/3A pump (Woesthoff). Mice breathed $8 \% \mathrm{O}_{2}$ for 2 to $108 \mathrm{~h}$ or were kept at room air. After hypoxic exposure, organs were removed and snap frozen in liquid nitrogen. The generation of fPSEN1/fPSEN1; $\alpha$ CaMKII-Cre;PSEN2ko mice was described previously (Saura et al., 2004).

RNA extraction and quantification. Total RNA from cells or from the cortex of fPSEN1/fPSEN1; $\alpha$ CaMKII-Cre;PSEN2ko mice was extracted as described previously (Wollenick et al., 2011). First-strand cDNA synthesis was performed with $1.5 \mu \mathrm{g}$ RNA using affinity script reverse transcriptase (RT) enzyme (Stratagene). mRNA expression levels were quantified by real-time quantitative PCR using a SYBR Green quantitative PCR reagent kit (Sigma) and a MX3000P cycler (Stratagene). Initial template concentrations of each sample were calculated by comparison with serial dilutions of a calibrated standard. To control for equal input levels, ribosomal protein S12 or L28 mRNA was determined and data were expressed as relative ratios.

Data analysis. Unless otherwise indicated, results are shown as mean values \pm SEM of at least three independent experiments. Statistical analysis was performed applying two-tailed or paired Student's $t$ test using GraphPad Prism Version 4.0 (GraphPad Software).

\section{Results}

\section{PSEN 1 and 2 regulate constitutive FKBP38 and PHD2 levels} and are ubiquitously expressed

To explore the function of PSEN1/2 in the hypoxia signaling pathway, PSEN1 and PSEN2 single as well as PSEN1/2 double ko MEFs (MEF PSEN1 ko, and MEF PSEN1/2 ko, respectively) were used (Herreman et al., 1999; 2003). As determined by immunoblotting, constitutive FKBP38 protein levels were increased, whereas PHD2 protein levels were strongly downregulated in PSEN1/2 ko MEFs (Fig. 1A, left). Quantification of relative band intensities of three independent experiments revealed 1.7-fold FKBP38 upregulation and fivefold PHD2 downregulation (Fig. $1 A$, right). This finding is consistent with a previous report that the lack of PSEN1/2 leads to increased FKBP38 protein abundance as well as with our published results on the negative regulation of PHD2 protein stability by FKBP38 (Wang et al., 2005; Barth et al., 2007).

Because FKBP38 was clearly less increased than PHD2 was decreased in PSEN1/2 ko MEFs, it is likely that at least one additional mechanism is involved in the regulation of PHD2 in cells lacking PSEN1/2. Quantitative RT-PCR analysis demonstrated that PHD2 mRNA levels were also significantly lower in PSEN1/2 ko MEFs, whereas there was no difference in FKBP38 mRNA levels (Fig. 1B). We further analyzed hypoxic PHD2 protein induction in PSEN1/2 wt and ko MEFs. Both normoxic and hypoxic $\mathrm{PHD} 2$ protein levels were substantially lower in the absence of PSEN1/2 at each time point tested (Fig. 1C). FKBP38 protein levels did not change in hypoxia, as reported previously (Barth et al., 2007). Relative hypoxic PHD2 induction, however, remained unchanged compared with normoxic PHD2 protein levels in each cell line (Fig. 1D).

In vivo, we found ubiquitous PSEN1/2 expression in adult mouse tissues with most abundant PSEN1 mRNA levels in the testis and the brain, and with high PSEN2 mRNA levels in the liver and the brain (Fig. 1E). Although exposure to inspiratory hypoxia $\left(8 \% \mathrm{O}_{2}\right)$ for 12 or $108 \mathrm{~h}$ induced mRNA levels of the 

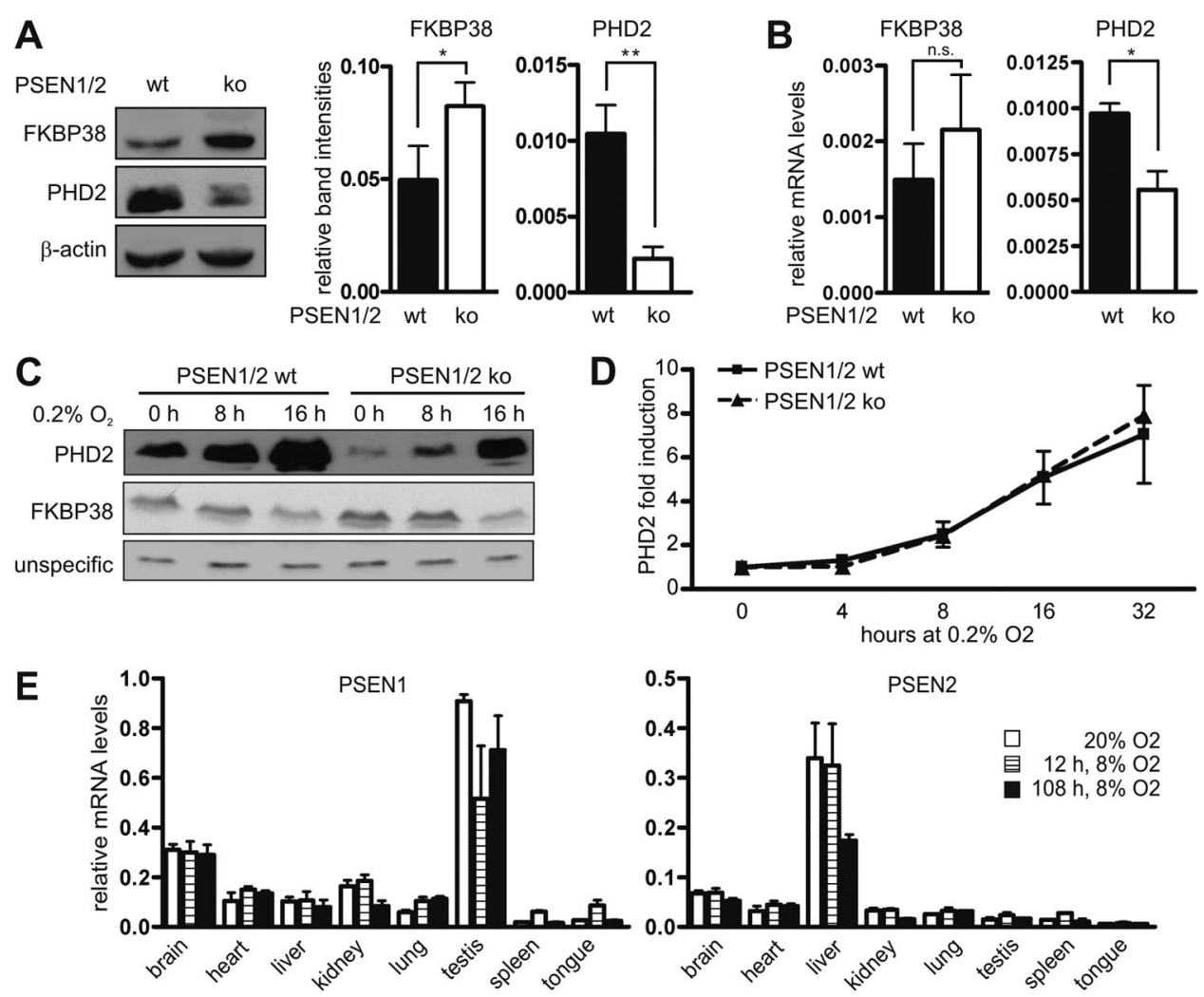

Figure 1. Regulation of FKBP38 and PHD2 by PSEN1 and PSEN2 in normoxia and hypoxia. $A$, Total cell extracts from PSEN1/2 wt and ko MEFs were analyzed for PHD2, FKBP38, and $\beta$-actin protein levels by immunoblotting (left). Relative band intensities of three independent experiments were quantified by densitometry (right). Data are shown as mean $\pm S D$ values. ${ }^{*} p<0.05$ ( $t$ test). ${ }^{* *} p<$ 0.005 ( $t$ test). $\boldsymbol{B}$, Total RNA was extracted from PSEN1/2 wt and ko MEFs. Transcript levels of FKBP38 and PHD2 were quantified by quantitative RT-PCR and normalized to ribosomal protein S12 mRNA levels. ${ }^{*} p<0.05$ ( $t$ test). n.s., Not significant. C, PSEN1/2 wt and ko MEFs were cultured in normoxia or hypoxia for the time indicated, and PHD2 and FKBP38 protein levels were analyzed by immunoblotting. $\boldsymbol{D}$, Relative band intensities of three independent experiments were quantified by densitometry. The $0 \mathrm{~h}$ time point of each cell line was defined as 1 . $\boldsymbol{E}$, Total RNA was derived from organs of mice that were kept at $20 \%$ or $8 \%$ oxygen for the time indicated. PSEN1 and PSEN2 transcript levels were quantified by quantitative RT-PCR and normalized to the ribosomal protein S12 mRNA levels. Data are shown as mean \pm SEM values of three independent RNA extractions from different mice.

HIF-target gene EPO in the brain by 25 -fold and 26-fold, respectively, and in the kidney by 168 -fold and 53 -fold, respectively (data not shown), no hypoxic induction of PSEN1 or PSEN2 itself could be detected, either in these mouse tissues (Fig. 1E) or in various human cell lines (data not shown).

\section{PSEN-deficient cells show an attenuated hypoxic response}

To investigate whether the constitutive decrease in PHD2 levels in PSEN1/2-deficient cells affects the hypoxic response functionally, wt, single ko, double ko, and lentivirally reconstituted MEFs were transiently cotransfected with a hypoxia response elementdriven firefly luciferase reporter gene together with a constitutive Renilla luciferase control vector. After transfection, cells were split and exposed to normoxia or hypoxia for $16 \mathrm{~h}$. Unexpectedly, despite decreased PHD2 levels, both hypoxic HIF- $1 \alpha$ protein levels and HIF-dependent reporter gene expression were decreased in PSEN1/2 ko MEFs (Fig. 2A). Reconstitution by lentiviral reexpression of wt PSEN1 (C1) or PSEN2 (C2) almost completely rescued the hypoxic HIF- $1 \alpha$ protein levels and reporter gene induction, excluding clonal artifacts and demonstrating that both PSEN1 and PSEN2 are independently involved in HIF regulation. Hypoxic induction of mRNA levels derived from the wellestablished HIF-target genes carbonic anhydrase (CAIX), PHD2, $\mathrm{N}$-myc downstream-regulated gene (NDRG1) and BCL2/adenovirus E1B interacting protein (BNIP3) was blunted in PSEN1/2 ko MEFs (Fig. 2B), confirming a functional decrease of endogenous HIF activity in the absence of PSEN1/2. Physiological oxy- gen partial pressures in the brain are in the range of $25-35 \mathrm{mmHg}$ (Baker, 1975), which corresponds to a gas phase oxygen concentration of $3-5 \%$. However, cultured cell lines adapted to $20 \% \mathrm{O}_{2}$ and exposed to $5 \% \mathrm{O}_{2}$ or lower will still react to this acute relative decrease in oxygen supply by an HIF- $\alpha$ induction (Stiehl et al., 2006). To confirm our findings in less severe hypoxia, PSEN $1 / 2$ wt and ko MEFs were cultured in $20 \%, 5 \%$, or $0.2 \% \mathrm{O}_{2}$ conditions for $16 \mathrm{~h}$ before HIF- $1 \alpha$ and PHD2 protein levels were analyzed by immunoblotting. Hypoxic HIF- $1 \alpha$ induction was blunted in PSEN1/2 ko MEFs, independent of the severity of relative hypoxia (Fig. 2C). Of note, hypoxic induction of the HIF-1 target gene PHD2 efficiently worked only at $0.2 \%$, an effect that can be explained by fine-tuning HIF- $1 \alpha$ transcriptional activity by FIH-mediated asparagine hydroxylation. Because FIH has a higher $\mathrm{O}_{2}$ affinity than the PHDs, HIF target genes, such as $\mathrm{PHD} 2$, are at best modestly increased after exposure to $5 \% \mathrm{O}_{2}$.

\section{PSEN1 is required for normal $\mathrm{Hifla}$ gene expression}

To further analyze the PSEN1/2-dependent regulation of the hypoxia pathway, HIF- $1 \alpha$ protein stability was examined. Because in normoxia HIF- $1 \alpha$ is virtually undetectable because of rapid hydroxylation-dependent proteasomal degradation, HIF- $1 \alpha$ protein decay was estimated under hypoxic conditions only. After $16 \mathrm{~h}$ of hypoxia, the translation inhibitor cycloheximide was added to PSEN1/2 wt and ko MEFs. HIF- $1 \alpha$ protein levels were analyzed by immunoblotting after $0,0.5,1,2$, and 4 h of ongoing hypoxia and cycloheximide treatment (Fig. 3A). Quantification of the 
A

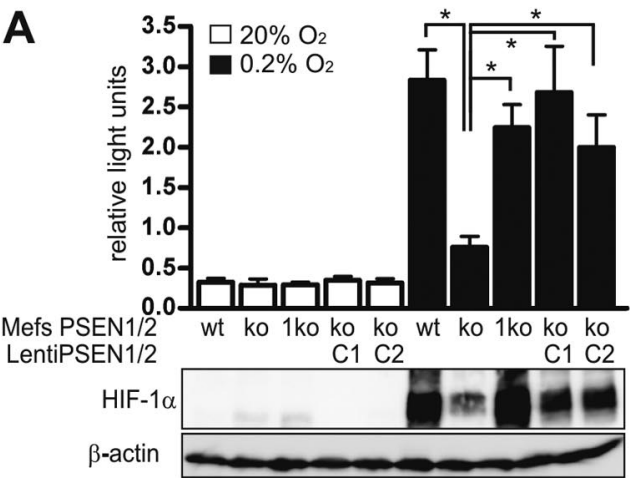

C

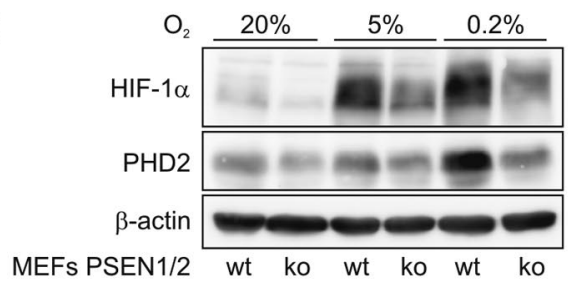

B

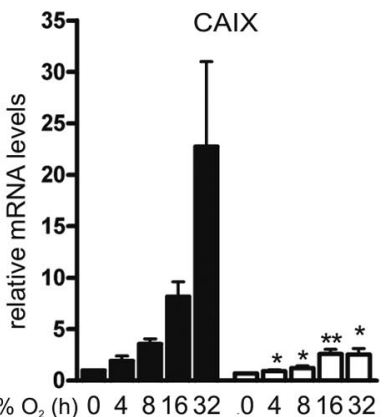

$0.2 \% \mathrm{O}_{2}(\mathrm{~h}) \frac{0481632}{04881632}$

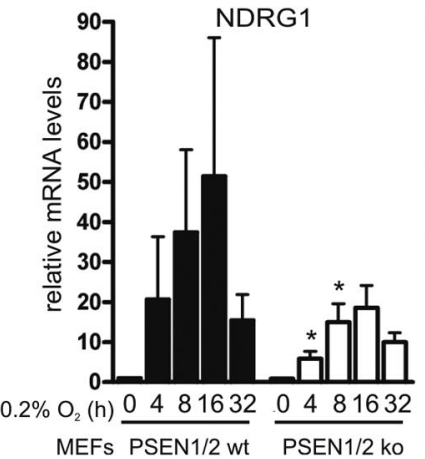

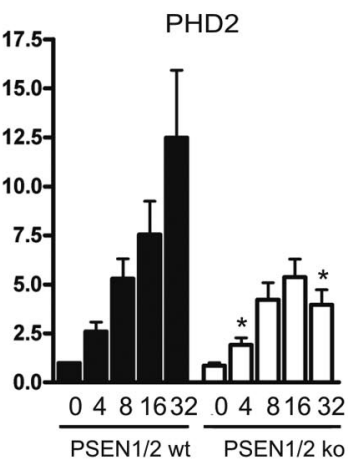

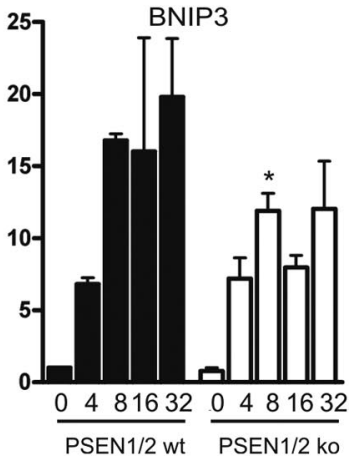

Figure 2. HIF transcriptional response to hypoxia in PSEN1/2-deficient cells. A, wt, PSEN1/2 ko (ko), PSEN1 ko (1ko), and two reconstituted clones of PSEN1/2 ko (C1 or C2) MEFs were transiently transfected with the HIF-dependent reporter pH3SVL and pRL-SV40 constructs and cultured in $20 \%$ or $0.2 \% 0$, for $16 \mathrm{~h}$ before relative luciferase activities were determined. The results are shown as mean \pm SEM values of three independent experiments performed in triplicates (top). HIF- $1 \alpha$ and $\beta$-actin protein levels were determined by immunoblotting (bottom). $\boldsymbol{B}$, PSEN1/2 wt and ko MEFs were cultured in $20 \%$ or $0.2 \% 0_{2}$ for $4,8,16$, and $32 \mathrm{~h}$ and total RNA was extracted. CAIX, PHD2, NDRG1, and BNIP3 transcript levels were quantified by RT-PCR and normalized to the expression of ribosomal protein S12 mRNA. Data are shown as mean \pm SEM values of five independent experiments. Student's $t$ tests were used to statistically evaluate the reduction (if any) of these $H I F$ target genes by PSEN1/2 deficiency at each time point. ${ }^{*} p<0.05 .{ }^{* *} p<0.01$. C, PSEN1/2 wt and ko MEFs were cultured in $20 \%, 5 \%$, or $0.2 \% 0_{2}$ for $16 \mathrm{~h}$ before HIF- $1 \alpha$, PHD2, and $\beta$-actin protein levels were analyzed by immunoblotting.

protein degradation rate of three independent experiments revealed that the hypoxic half-life of HIF- $1 \alpha$ protein was $\sim 2.5 \mathrm{~h}$ and did not differ between the two cell lines (Fig. $3 B$ ).

Because HIF- $1 \alpha$ protein stability was not altered in PSEN1/2 ko MEFs, HIF- $1 \alpha$ mRNA levels were determined by quantitative RT-PCR. Transcript levels in PSEN1/2 ko MEFs were decreased by almost $50 \%$ compared with the wt control (Fig. 3C). To determine HIF- $1 \alpha$ mRNA stability in PSEN1/2 wt and ko MEFs, cells were treated with actinomycin $\mathrm{D}$ for up to $24 \mathrm{~h}$ and transcript levels quantified by quantitative RT-PCR. Neither HIF- $1 \alpha$, PHD2, nor VEGFA mRNA stability was found to be altered in PSEN1/2 ko MEFs (Fig. $3 D$ ), suggesting that HIF- $1 \alpha$ mRNA is transcriptionally regulated and not via degradation.

Because Hifla promoter activity likely is responsible for the difference in HIF- $1 \alpha$ mRNA levels, a previously published 885 bp fragment upstream of the transcriptional start site of the mouse Hifla gene, cloned into a promoterless firefly luciferase reporter gene vector (Wenger et al., 1998), was used to determine HIF- $1 \alpha$ transcription rates. A cotransfected pSV40Renilla vector served as an internal control to correct for differences in transfection efficiency and extract preparation. Luciferase expression was determined $48 \mathrm{~h}$ after transfection, and values were normalized to the activity of the promoterless vector pGL3basic in wt MEFs. As shown in Figure 3E, Hif1a promoter activity was significantly lower in PSEN1/2 ko than in wt MEFs. Hifla promoter activity was rescued to almost wt levels in two different clones of ko MEFs that were lentivirally reconstituted with PSEN1/2.
$\gamma$-Secretase enzymatic activity is required for PSENdependent regulation of HIF-1 $\alpha$ but not of FKBP38/PHD2 Most of the known functions of PSEN1/2 require $\gamma$-secretase proteolytic activity (Wakabayashi and De Strooper, 2008). To determine whether $\gamma$-secretase activity is also required for the regulation of the hypoxia pathway, PSEN1/2 wt and ko MEFs were cultured under normoxic or hypoxic conditions for $12 \mathrm{~h}$ in the presence of either DMSO alone (control) or 2 or $4 \mu \mathrm{M}$ DAPT, a specific $\gamma$-secretase inhibitor. As shown in Figure $4 A$, inhibition of $\gamma$-secretase activity reduced HIF- $1 \alpha$ protein levels but did not have any effect on FKBP38 or PHD2 protein levels. The accumulation of the $\mathrm{C}$-terminal fragment of $\mathrm{N}$-cadherin served as a control for DAPT function. This finding further supports that the regulation of the hypoxia pathway takes place on more than one level, comprising $\gamma$-secretase-dependent and $\gamma$-secretaseindependent mechanisms. To confirm our results in neuronal cells, SH-SY5Y neuroblastoma cells were treated with either DMSO alone (control) or with 2 or $4 \mu \mathrm{M}$ DAPT before exposure to $20 \%$ or $0.2 \% \mathrm{O}_{2}$ for $16 \mathrm{~h}$. $\gamma$-Secretase inhibition using $4 \mu \mathrm{M}$ DAPT reduced hypoxic HIF- $1 \alpha$ protein levels by $24 \%$ but did not affect PHD2 protein levels in SH-SY5Y cells (Fig. 4B).

Notch is one of the many $\gamma$-secretase substrates and has been described to potentiate the hypoxic response in certain cell lines on various levels, involving the direct interaction of HIF- $1 \alpha$ with Notch intracellular domain (NICD) and the recruitment of HIF- $1 \alpha$ to NICD responsive promoters (Gustafsson et al., 2005). To analyze whether PSENs act on the hypoxia pathway via Notch signaling, HeLa/trTAA/TRE-N1-IC cells were used, allowing in- 

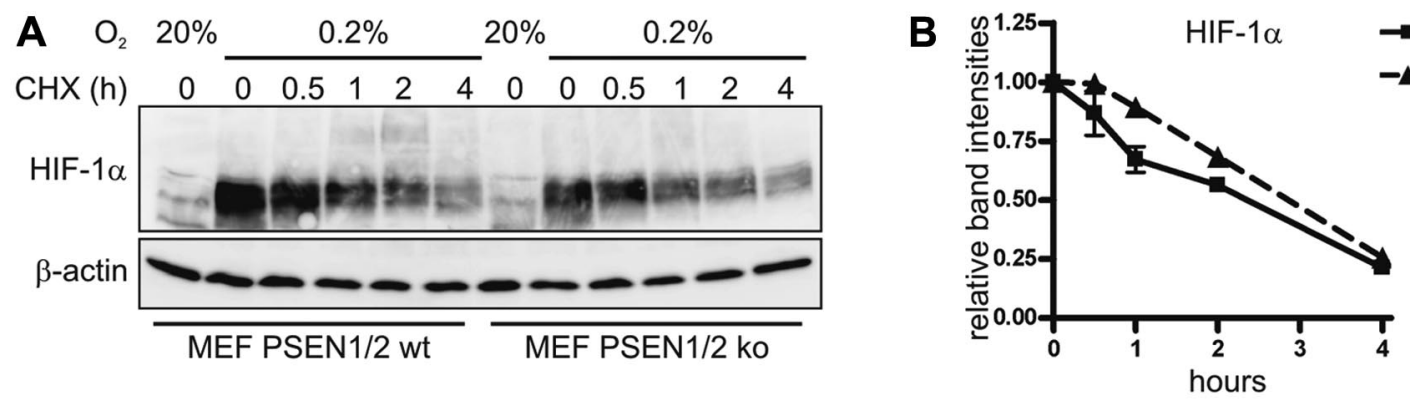

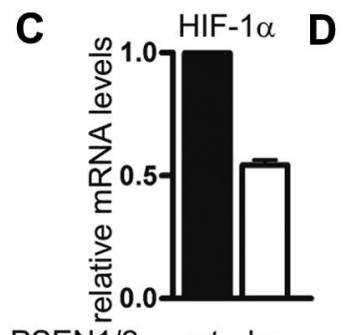

PSEN1/2 wt ko
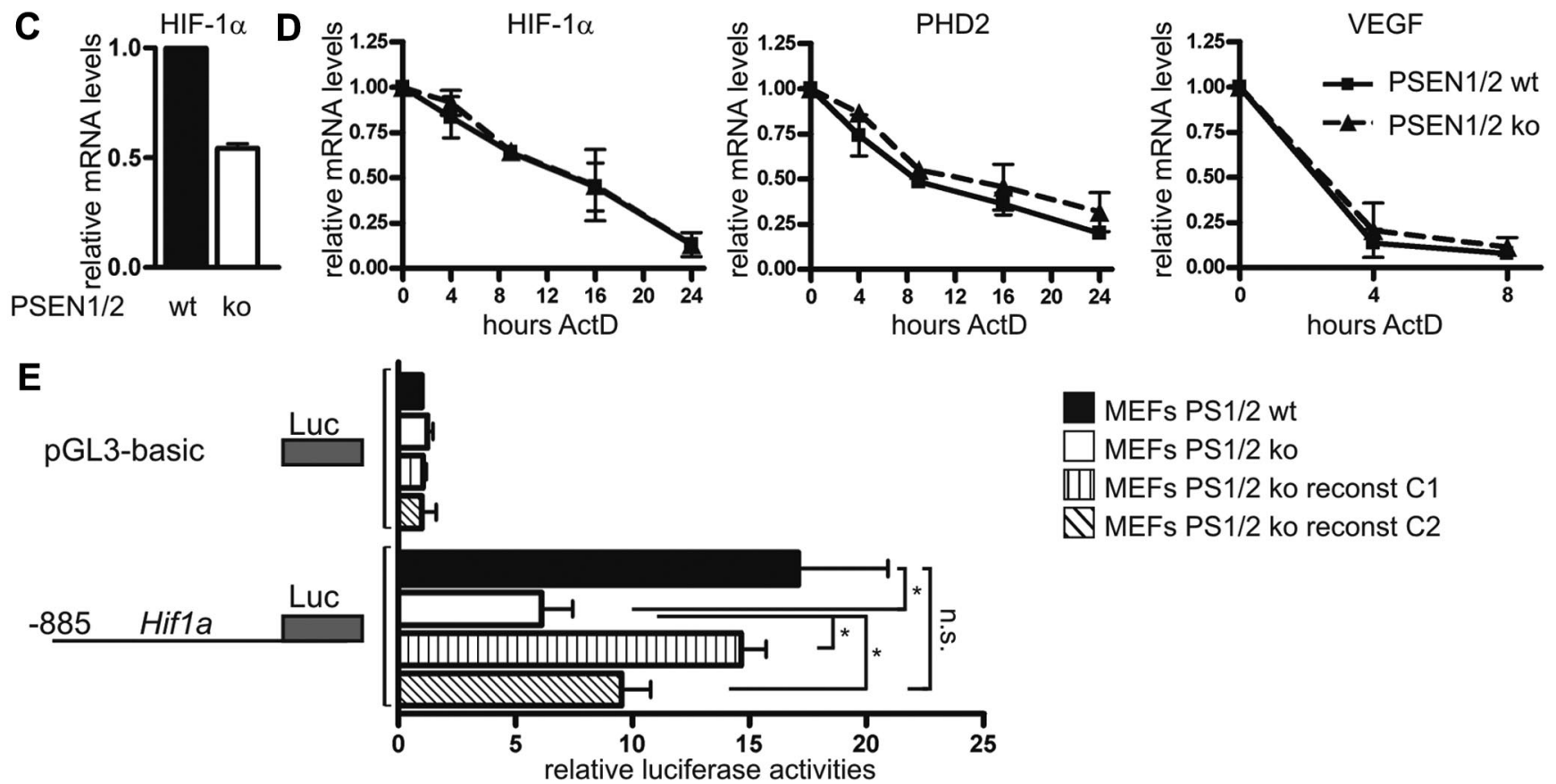

Figure 3. HIF- $1 \alpha$ regulation in PSEN1/2-deficient cells. A, PSEN $1 / 2$ wt and ko MEFs were cultured in $20 \%$ or $0.2 \%{ }_{2}$ for $16 \mathrm{~h}$ before treatment with $100 \mu \mathrm{m}$ cycloheximide. Total cell extracts were prepared after $0.5,1,2$, and $4 \mathrm{~h}$ of treatment. HIF- $1 \alpha$, and $\beta$-actin protein levels were analyzed by immunoblotting. $\boldsymbol{B}$, Relative band intensities of three independent experiments were quantified relative to the $\beta$-actin levels and normalized to the $0 \mathrm{~h}$ hypoxia time points. Mean values \pm SEM of three independent experiments are shown. C, Quantification of HIF- $1 \alpha$ mRNA levels in PSEN $1 / 2$ wt and ko MEFs by quantitative RT-PCR. Transcript levels were normalized to the mRNA levels of ribosomal protein S12, and the wt level was defined as 1.D, PSEN1/2 wt and ko MEFs were incubated at $0.2 \% 0_{2}$ for $16 \mathrm{~h}$ before $5 \mu \mathrm{g} / \mathrm{ml}$ actinomycin D was added to the cells. Total RNA was extracted after $0,4,8,16$, and $24 \mathrm{~h}$ of actinomycin D treatment, and HIF- $1 \alpha$, PHD2, and VEGFA transcript levels were quantified by RT-PCR. mRNA levels were normalized to ribosomal protein $S 12 \mathrm{mRNA}$, and the $0 \mathrm{~h}$ time point was defined as 1 . The results are shown as mean $\pm S E M$ values of three independent experiments. E, PSEN1/2 wt, ko, and two PSEN1/2 reconstituted clones were transiently cotransfected with the Hif1a promoter-driven pGL3-885Hif1a or the promoterless pGL3-basic plasmid together with the PSV40-RL control vector. Data were normalized to the Renilla luciferase activities and are shown as mean \pm SEM values of three independent experiments performed in triplicates. ${ }^{*} p<0.05$, $(t$ test). n.s., Not significant ( $t$ test).

duced expression of the human Notch1-IC by doxycycline (Lee et al., 2009). Protein levels of doxycycline or vehicle-treated HeLa cells were analyzed after $16 \mathrm{~h}$ exposure to $20 \%$ or $0.2 \% \mathrm{O}_{2}$. As shown in Figure 4C, hypoxic accumulation of HIF- $1 \alpha$ and PHD2 were not affected by NICD induction. Consistently, although PHD2, CAIX, and GLUT1 mRNA levels were induced 2.5- to 100-fold after $16 \mathrm{~h}$ of hypoxic exposure, they remained unchanged by NICD induction (Fig. $4 D$ ). Increased SNAIL mRNA levels confirmed the activation of the Notch pathway (Fig. 4D). These findings suggest that PSEN-dependent HIF regulation in our models is not the result of alterations in the Notch signaling pathway.

Gain-of-function as well as (partial) loss-of-function mutations in PSEN1/2 are strongly associated with FAD. Therefore, we sought to analyze the effects of several clinically relevant PSEN mutations on the hypoxia pathway by using PSEN1/2 wt and ko MEFs, or ko MEFs stably reconstituted with human PSEN mutants commonly found in FAD patients (PSEN1- $\triangle E$ 9, PSEN1-A246E, PSEN1-L166P, PSEN1G384A, and PSEN2-NI41I) (Bentahir et al., 2006). These cells were transiently transfected with the HIF-dependent reporter gene
pH3SVL and luciferase activity was measured after $16 \mathrm{~h}$ of exposure to either $20 \%$ or $0.2 \% \mathrm{O}_{2}$. Whereas reintroduction of PSEN1A246E, PSEN1-G384A, and PSEN2-N141I partially rescued HIF activity in hypoxic PSEN1/2 ko MEFs, PSEN1- $\triangle$ E9 and PSEN1-L166P failed to do so (Fig. 4E). Of note, whereas the former three mutations are still able to cleave some substrates (e.g., APP) but not others (e.g., Notch), $\gamma$-secretase function of the latter two mutations has been shown to be severely impaired and to abolish canonical APP cleavage as well as NICD formation (Bentahir et al., 2006; Shen and Kelleher, 2007), confirming the results obtained with the DAPT $\gamma$-secretase inhibitor.

\section{Regulation of HIF- $1 \alpha$ protein and mRNA levels via APP/AICD}

The finding that MEFs bearing PSEN mutations that are unable to generate the NICD but still cleave the APP show a functional hypoxic response led us to hypothesize that AICD might be crucial for HIF regulation. Therefore, HIF- $1 \alpha$ protein levels were determined in HEK293-citAICD, a human embryonic kidney cell line that allows for tebufenozide induction of AICD expression (von Rotz 
et al., 2004). After tebufenozide treatment, HIF- $1 \alpha$ but not PHD2 protein levels were increased (Fig. 5A, left). Because normoxic HIF- $1 \alpha$ protein is rapidly degraded and therefore not detectable, HIF- $1 \alpha$ protein levels were analyzed in $\mathrm{HEK}$-cit AICD grown in $20 \% \mathrm{O}_{2}$ using prolonged exposure times. As shown in Figure $5 A$, right panel, also normoxic HIF- $1 \alpha$ protein levels were induced after AICD overexpression. On the mRNA level, HIF- $1 \alpha$ and its target genes PHD2 and CAIX were increased after AICD overexpression under normoxic conditions as well as after $4-24 \mathrm{~h}$ of hypoxic exposure (Fig. 5B). The overall oxygenindependent HIF- $1 \alpha$, PHD2, and CAIX mRNA levels increased significantly by 40,19 , and $95 \%$, respectively $(p<0.05$, paired Student's $t$ test). AICD overexpression was verified by immunoblotting (Fig. 5A) as well as quantitative RT-PCR (Fig. 5B).

To further explore the involvement of APP/AICD in the hypoxic response, we analyzed HIF- $1 \alpha$ and PHD2 protein levels in APP wt, APP ko, and APP/APP-like protein 2 (APLP2) double ko MEFs by immunoblot analysis. APLP2 has been shown to be able to partially take over the function of APP (Heber et al., 2000; Yang et al., 2005). Hypoxic HIF- $1 \alpha$ accumulation was blunted in the absence of APP alone and was further decreased slightly in APP/APLP2 ko MEFs on both the protein (Fig. 5C) and the mRNA levels (Fig. 5D). Although the HIF-1 target gene PHD2 was not significantly affected, the overall oxygen-independent CAIX mRNA levels decreased significantly by $56 \%(p<0.05$, paired Student's $t$ test) in APP/APLP2 ko MEFs (Fig. 5D). Finally, we investigated whether AICD overexpression is sufficient to rescue the blunted hypoxic response after $\gamma$-secretase inhibition. Therefore, AICD overexpression in Hek293-citAICD cells was induced for $16 \mathrm{~h}$ before $\gamma$-secretase activity was blocked by DAPT treatment for $8 \mathrm{~h}$ and the cells incubated at $20 \%$ or $0.2 \% \mathrm{O}_{2}$. Whereas AICD overexpression resulted in increased hypoxic HIF- $1 \alpha$ protein levels, $\gamma$-secretase inhibition reduced HIF- $1 \alpha$ but not PHD2 protein levels in the presence and absence of $\mathrm{AICD}$ (Fig. $5 E, F$ ). These findings indicate that the APP/AICD cleavage cascade is involved in $\mathrm{PHD} / \mathrm{HIF}$ signaling but is likely not the only $\gamma$-secretase substrate involved in these effects.

Decreased HIF- $1 \alpha$ expression in the cortex of forebrain-specific PSEN1/2 conditional double knock-out mice

To confirm the relevance of our findings in vivo, we analyzed the cortex region of forebrain-specific fPSEN1/fPSEN1; $\alpha$ CaMKIICre;PSEN2ko PSEN1/2 conditional double knock-out (PSEN1/2

$\mathbf{E}$ performed in triplicates.

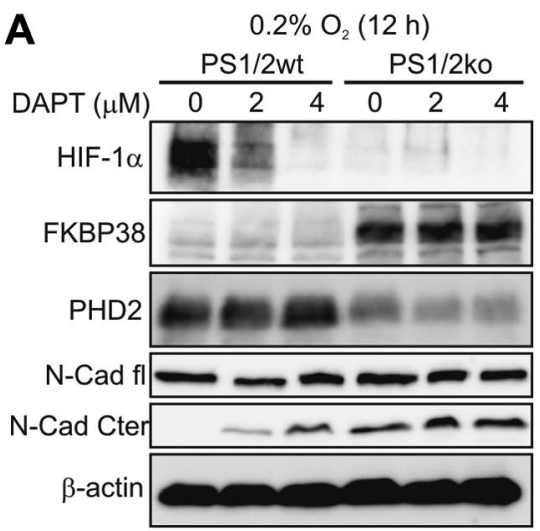

B

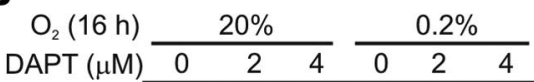

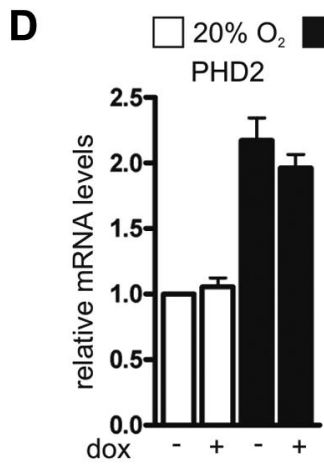

$0.2 \% \mathrm{O}_{2}(16 \mathrm{~h})$
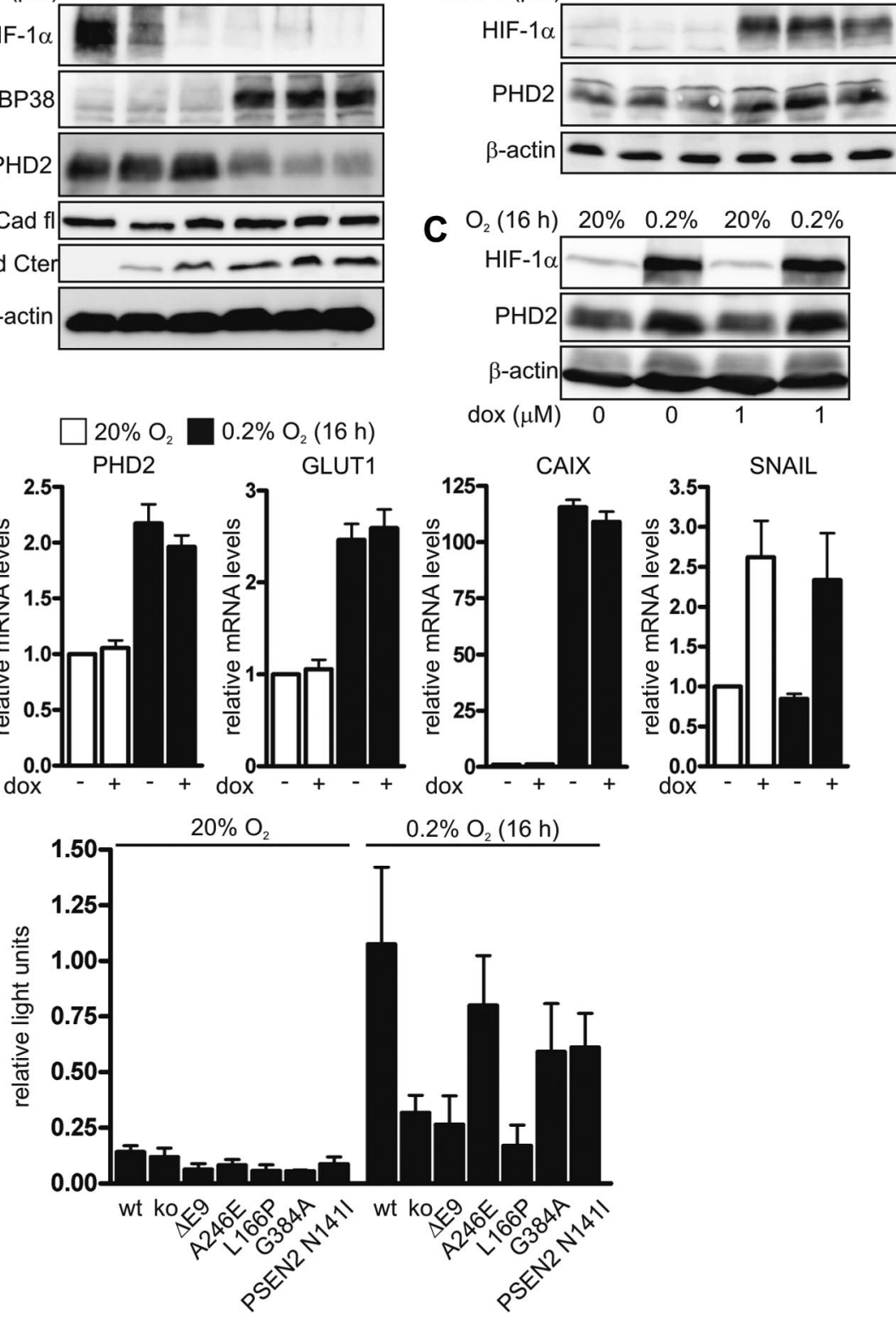

Figure 4. Requirement of $\gamma$-secretase enzymatic activity for presenilin-dependent regulation of HIF-1 $\alpha$, FKBP38, and PHD2.A PSEN1/2 wt and ko MEFs were pretreated with 0,2 , or $4 \mu \mathrm{m}$ of the $\gamma$-secretase inhibitor DAPT before culturing at $0.2 \% 02$ for $12 \mathrm{~h}$. HIF-1 $\alpha$, FKBP38, PHD2, $N$-cadherin, and $\beta$-actin protein levels were determined by immunoblotting. $\boldsymbol{B}$, SH-SY5Y cells were cultured at $20 \%$ or $0.2 \% 0_{2}$ for $16 \mathrm{~h}$ in the presence of 0,2 , or $4 \mu \mathrm{M}$ DAPT, and HIF-1 $\alpha$, PHD2, and $\beta$-actin protein levels were analyzed by immunoblotting. $C, D$, HeLa/trTAA/TRE-N1-ICD cells were cultured for $24 \mathrm{~h}$ in the presence or absence of $1 \mu \mathrm{m}$ doxycycline before exposure to $20 \%$ or $0.2 \% 0_{2}$ for $16 \mathrm{~h}$. Thereafter, HIF- $\alpha$, PHD2, and $\beta$-actin protein levels were determined by immunoblotting ( $\boldsymbol{C}$ ) and PHD2, GLUT1, CAIX, and Snail mRNA levels were quantified by quantitative RT-PCR (D). Transcript levels were normalized to the mRNA levels of ribosomal protein $L 28$. The untreated normoxic control was defined as 1. Data are shown as mean \pm SEM values of three independent experiments. $E$, PSEN1/2 wt, ko, and ko MEFs stably expressing PSEN1 or PSEN2 FAD mutations ( $\triangle E$ 9, A246E, L166P, G384A, and N141I) were transiently cotransfected with the hypoxia response element-driven luciferase reporter plasmid (pH3SVL) together with the pSV40-RL control vector. Cells were cultured for $16 \mathrm{~h}$ at $20 \%$ or $0.2 \% 02$ before luciferase activity was determined. The results are shown as mean \pm SEM values of three independent experiments cdko) mice (Saura et al., 2004). HIF-1 $\alpha$, HIF-2 $\alpha$, PHD2, and VEGFA mRNA levels were found to be significantly downregulated in the cortex of these mice, whereas there was no difference in FKBP38 and the HIF-target gene NDRG1 mRNA levels (Fig. $6 A)$. In line with the mRNA levels, PHD2 protein levels were 
A

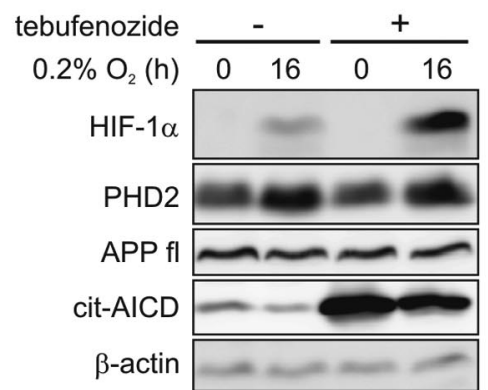

C

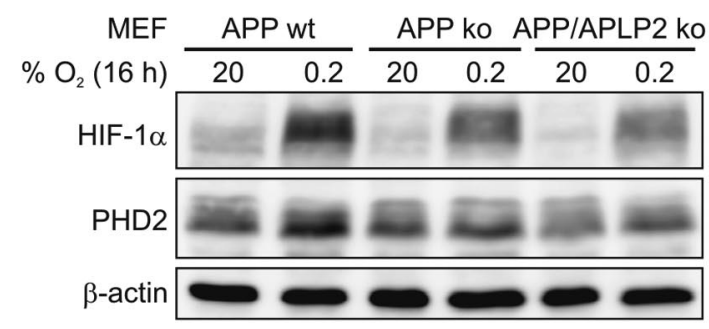

B

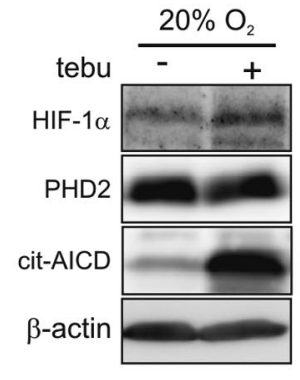

$0.2 \% \mathrm{O}_{2}$

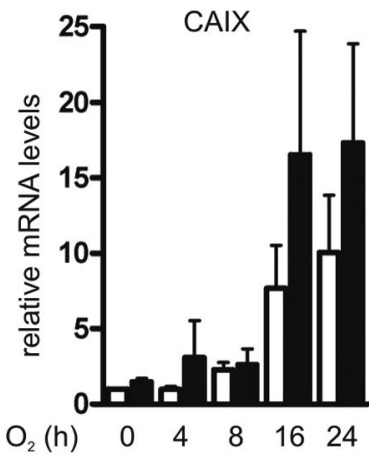

$0.2 \% \mathrm{O}_{2}(\mathrm{~h}) \quad 0 \quad 4 \quad 4 \quad 8 \quad 16 \quad 24$
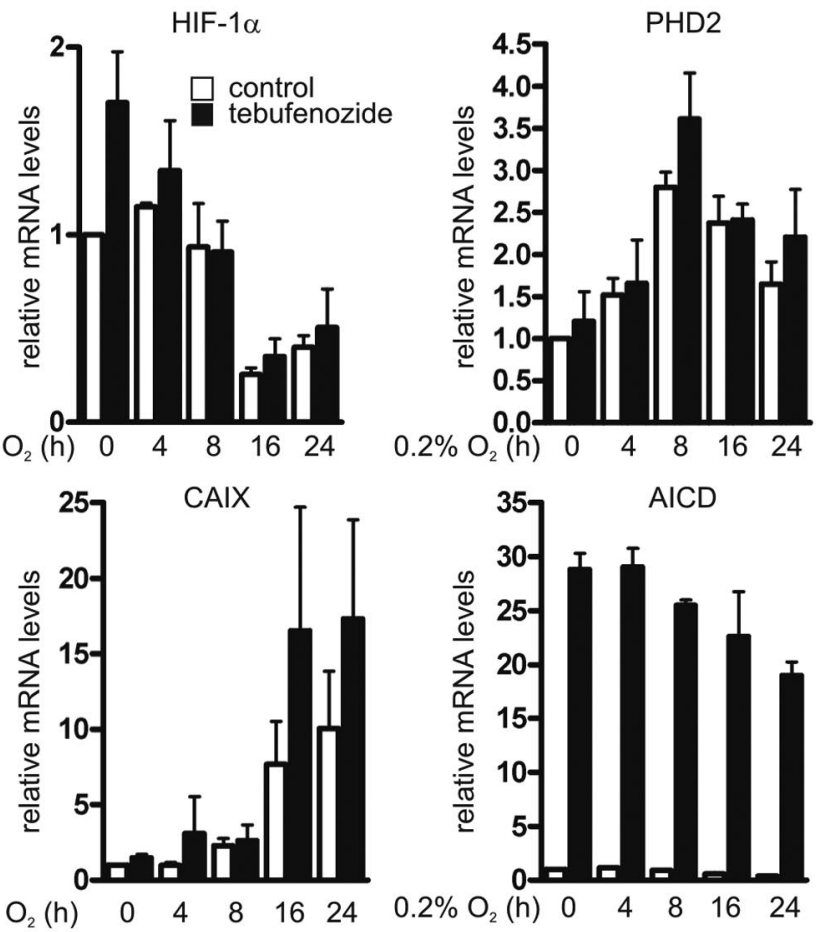

D

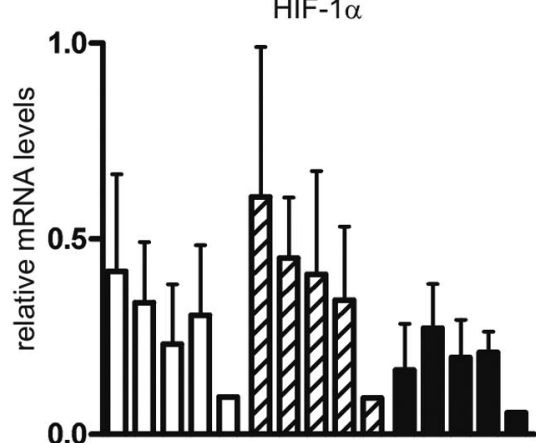

$0.2 \% \mathrm{O}_{2}$ (h) 048162404816240481624

MEF APP wt $\overline{\text { APP ko APP/LP2 ko }}$

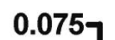

0.075

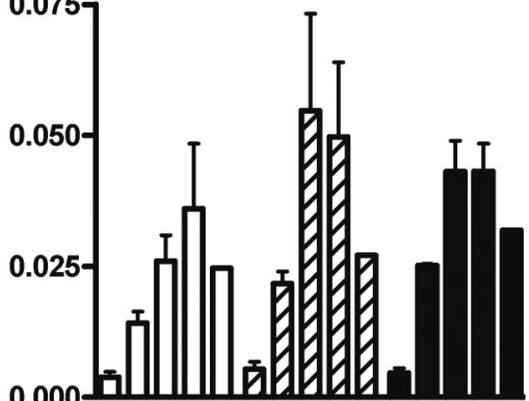

048162404816240481624

APP wt $\overline{\text { APP ko APP/LP2 ko }}$

CAIX

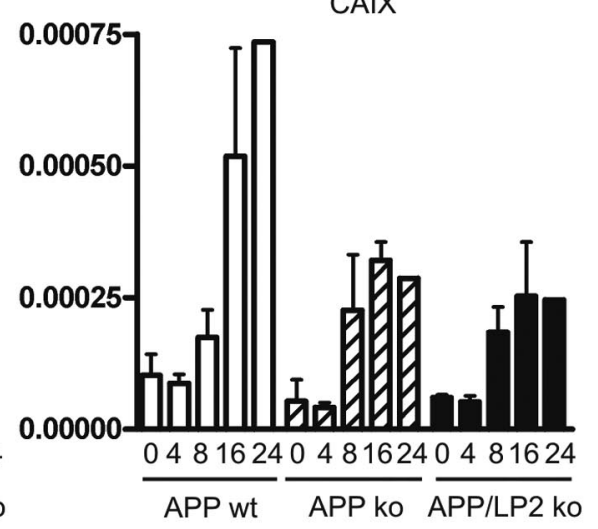

E
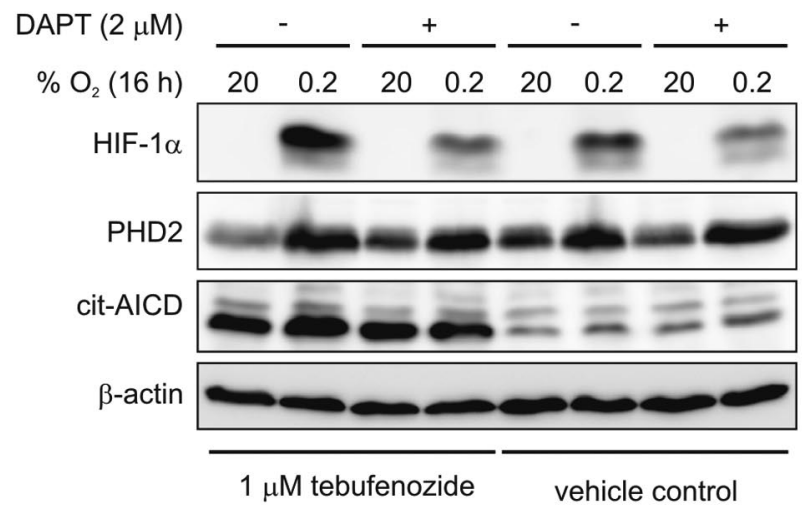

$\mathbf{F}$

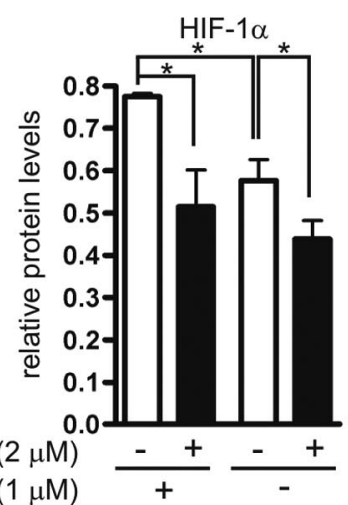

Figure 5. Regulation of HIF by the APP/AICD cleavage cascade. A, Hek293-citAICD cells were pretreated with $1 \mu \mathrm{m}$ tebufenozide for $24 \mathrm{~h}$ before culturing at $20 \%$ or $0.2 \% 0$, for $16 \mathrm{~h}$ and determination of HIF- $1 \alpha$, PHD2, APP, and $\beta$-actin by immunoblotting (left). In a separate experiment, normoxic HIF- $1 \alpha$ was detected using a prolonged exposure time (right). $\boldsymbol{B}$, Hek293-citAICD cells were cultured for $24 \mathrm{~h}$ in the presence or absence of $1 \mu \mathrm{m}$ tebufenozide and exposed to $20 \%$ or $0.2 \% 0_{2}$ for the time indicated, before mRNA levels of HIF-1 $\alpha$, PHD2, CAIX, and AICD were quantified by RT-PCR. The transcript levels were normalized to ribosomal protein L28 mRNA levels, and the zero hour time point of the control cells was defined as 1. C, APP wt, APP ko, and APP/APPLP2 ko MEFs were cultured at $20 \%$ or $0.2 \% 0_{2}$ for $16 \mathrm{~h}$, and HIF- $1 \alpha$, PHD2, and $\beta$-actin protein levels were determined by immunoblotting. D, APP wt, APP ko, and APP/APLP2 ko MEFs were exposed to $0,4,8,16$, or $24 \mathrm{~h}$ of $0.2 \% 0_{2}$, and mRNA levels of HIF- $1 \alpha$, PHD2, and CAIX were quantified by RT-PCR. Transcript levels were normalized to ribosomal protein S12 mRNA levels. $\boldsymbol{E}$, $\boldsymbol{F}$, Hek293-citAICD cells were grown in the presence or absence of $1 \mu \mathrm{m}$ tebufenozide for $16 \mathrm{~h}$ before $8 \mathrm{~h}$ pretreatment with DMSO or DAPT and subsequent incubation at $20 \%$ or $0.2 \% 0_{2}$ for $16 \mathrm{~h}$. HIF- $1 \alpha$, PHD2, and AICD were determined by immunoblotting $(\boldsymbol{E})$, and HIF- $1 \alpha$ band intensities were quantified and normalized to $\beta$-actin $(\boldsymbol{F})$. Data are shown as mean \pm SEM values of three independent experiments. ${ }^{*} p<0.05$ ( $t$ test). 
decreased by $\sim 65 \%$, whereas FKBP38 protein remained unaffected in the cortex of PSEN1/2 cdko mice (Fig. $6 B, C$ ). Furthermore, we investigated BACE1 expression levels, which have been shown previously to be induced by hypoxia in a HIF-dependent manner (Zhang et al., 2007). In line with this report, BACE1 mRNA levels were lower in the brain of PSEN1/2 cdko mice (Fig. 6A).

In summary, our findings demonstrate that PSEN1/2 are involved in the regulation of the oxygen-sensing pathway in cells of various origins in vitro as well as in cortical neurons in vivo.

\section{Discussion}

Many neurological diseases, such as $\mathrm{AD}$ and $\mathrm{PD}$, are characterized by tissue hypoxia, but whether hypoxia is a cause or a consequence of the disease remains unclear (Peers et al., 2009). In this report, we show that PSEN1 and PSEN2 modulate the functional response to hypoxia on more than one level (schematically summarized in Fig. 7). MEFs lacking PSEN1/2 showed increased constitutive FKBP38 and concomitantly decreased PHD2 protein levels. These findings are in line with a previous report, showing that genetic ablation of PSEN1/2 increases FKBP38 protein levels (Wang et al., 2005) and with our previous results showing that FKBP38 negatively regulates PHD2 protein levels (Barth et al., 2009). Neither PSEN1 nor PSEN2 was regulated by hypoxia in any of the mouse tissues or cell lines analyzed, even though some reports showed an induction of PSEN1 after hypoxic exposure of glial cells (Bazan and Lukiw, 2002; Cui et al., 2004). However, FKBP38 protein levels were only slightly upregulated, suggesting that additional mechanisms contribute to the decreased PHD2 levels. Consistently, not only PHD2 protein but also mRNA levels were substantially downregulated in PSEN1/2-deficient MEFs.

Because we and others previously showed that even slight changes in PHD2 protein levels affect HIF- $1 \alpha$ protein stability (Stiehl et al., 2006; Ginouvès et al., 2008; Henze et al., 2010), the clearly reduced PHD2 levels in PSEN1/2-deficient MEFs led us to expect that HIF- $1 \alpha$ protein and HIF target gene expression will be induced in these cells. However, quite surprisingly, PSEN1/2deficient MEFs also showed a decreased HIF response, despite the strongly decreased PHD2. Because PHD2 is a direct target of HIF- $1 \alpha$, these findings might provide the additional mechanism involved in PHD2 downregulation, but they cannot explain the HIF- $1 \alpha$ downregulation. PHD3 protein levels were not affected by the loss of PSEN1/2, whereas PHD1 expression was almost undetectable in PSEN1/2 wt and ko MEFs (data not shown).

Interestingly, the lack of PSEN1/2 lowered both Hifla promoter activity and HIF- $1 \alpha$ mRNA levels in MEFs. In line with the in vitro data, HIF- $1 \alpha$, HIF- $2 \alpha$, PHD2, and VEGFA RNA and PHD2 protein levels were decreased in the cortex of forebrainspecific PSEN1/2 cdko mice. These in vitro and in vivo results confirm previous descriptive in vivo gene array data demonstrat- ing that HIF- $1 \alpha$ mRNA levels are decreased in PSEN1 hypomorphic mice (Liauw et al., 2002; Rozmahel et al., 2002). However, it is currently unclear whether the $50 \%$ decrease in HIF- $1 \alpha$ mRNA levels alone could explain the more pronounced (80\%) decrease in hypoxic HIF- $1 \alpha$ protein. During the progression of our study, De Gasperi et al. (2010) showed that PSEN1 ko MEFs display impaired induction of HIF- $1 \alpha$ after stimulation with hypoxia mimetics, insulin, and calcium chelators (De Gasperi et al., 2010). These authors attributed their findings to a shorter half-life of HIF- $1 \alpha$ in PSEN1-deficient MEFs. However, using PSEN1/2deficient MEFs, we could not find any decrease in HIF- $1 \alpha$ protein stability. Two main differences between our experiments and those performed by De Gasperi et al. (2010) might explain this discrepancy: (1) we conducted our analysis in double-ko MEFs; and (2) we measured HIF- $1 \alpha$ decay after a controlled hypoxic accumulation because HIF- $1 \alpha$ is normally not detectable under normoxic conditions.

Together with PSEN enhancer (Pen-2), nicastrin, and anterior pharynx 1 (Aph-1), PSENs form the core of the $\gamma$-secretase complex that cleaves a variety of type I transmembrane proteins (De Strooper et al., 1999; Parks and Curtis, 2007). Several studies implied that PSEN also have $\gamma$-secretase-independent functions (reviewed by Wakabayashi and De Strooper, 2008). Accordingly, we showed that, although the $\gamma$-secretase function of PSEN $1 / 2$ is essential for hypoxic HIF- $1 \alpha$ induction, it does not affect the protein levels of FKBP38 and PHD2, further underlining that at 


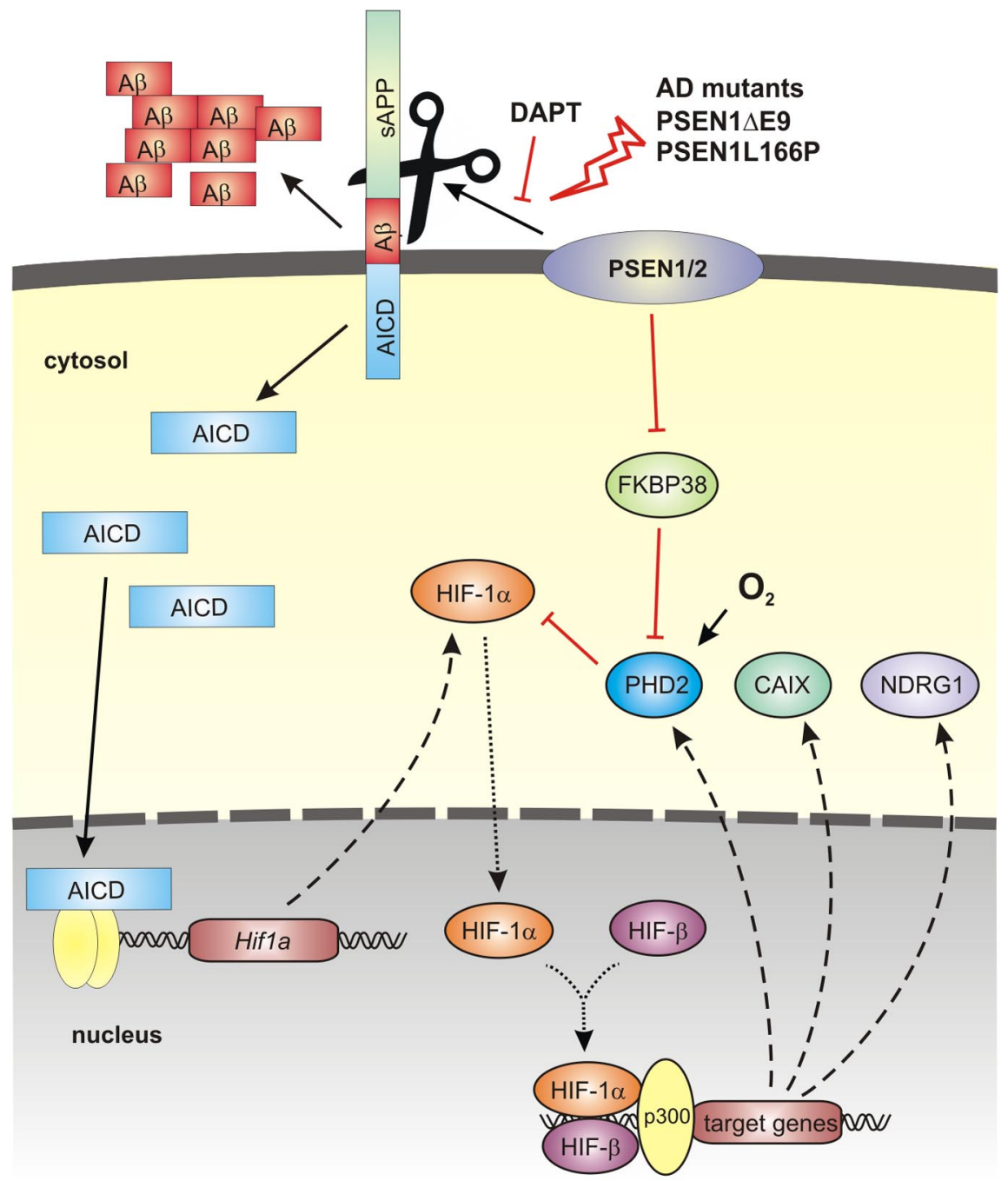

Figure 7. Scheme of the mechanisms involved in the regulation of HIF by PSENs. PSEN1/2 $\gamma$-secretase-mediated cleavage of the APP generates $A \beta$ involved in AD as well as the AICD that induces Hifla gene expression and HIF- $1 \alpha$ protein stability but does not regulate FKBP38/PHD2. On the other hand, PSEN1/2 increases PHD2 activity by inhibiting FKBP38 in a $\gamma$-secretaseindependent manner. These two mechanisms overlap with hypoxic induction of HIF- $1 \alpha$ protein stability and finally converge in the downregulation of HIF-dependent target gene expression after deletion or functional mutation of PSEN1/2.
HIF- $1 \alpha$ protein accumulation, even in the presence of overexpressed AICD, additional $\gamma$-secretase substrates are likely to be involved in HIF regulation. A recent report by Le Moan et al., 2011 showed that $\gamma$-secretase activity is increased in hypoxia by an unknown mechanism, leading to increased HIF- $1 \alpha$ stability. Even though PSEN1/2 was not investigated, we found that genetic ablation of the $\gamma$-secretase substrate p75 neurotrophin receptor reduced hypoxic HIF-1 $\alpha$ stabilization. Their findings were explained through decreased Siah2 abundance after p75 abrogation. Siah2 has been proposed previously to negatively regulate PHD1 and PHD3, and decreased Siah2 hence would lead to lowered HIF- $1 \alpha$ protein and HIF target gene expression (Nakayama et al., 2004). Accordingly, Le Moan et al., 2011 found decreased PHD3 mRNA levels as a result of a blunted HIF-response in p75 ko MEF cells. However, in our hands, overexpression of the full-length p75 or the p75 intracellular domain did not affect hypoxic HIF- $1 \alpha$ protein levels, suggesting that the p75/p75ICD cascade is not the major regulator of the hypoxia pathway in our cellular model (data not shown). To date, it remains unclear which other $\gamma$-secretase substrate(s) in addition toAPP/ AICD is/are involved in the regulation of the HIF signaling cascade. Furthermore, DAPT inhibits the cleavage of endogenous APP. Fe65 binds APP and is thus less available for binding the overexpressed AICD to translocate with it into the nucleus (Cao and Sudhof, 2001; Wiley et al., 2007). This might be an additional explanation for the decreased HIF- $1 \alpha$ protein levels after DAPT treatment in the presence of overexpressed AICD.

To investigate the role of APP and least two independent mechanisms are involved in PSENdependent HIF regulation.

NICD and AICD are two major $\gamma$-secretase-dependent intracellular cleavage products (derived from the Notch and APP precursors, respectively), and NICD has been shown previously to potentiate the HIF response in neuronal and myogenic cells (Gustafsson et al., 2005). However, in the cell models used in this study, AICD but not NICD regulated HIF- $1 \alpha$ and HIF target gene expression. The function of AICD remains incompletely understood, but it has been shown to be present in nuclear complexes involved in nuclear signaling (Cao and Sudhof, 2001; von Rotz et al., 2004). Nuclear signaling function of AICD requires its association with the APP adaptor protein Fe65 and the histone acetyltransferase Tip60 (Cao and Sudhof, 2001). Of note, several genes regulated by AICD have been identified, including KAI1 (Baek et al., 2002), glycogen synthase $3 \beta$ (Kim et al., 2003), APP, and BACE (von Rotz et al., 2004). Our results suggest that HIF- $1 \alpha$ might represent a novel AICD target gene, but further mechanistic experiments need to be performed to corroborate this hypothesis. Because $\gamma$-secretase inhibition decreased hypoxic
APLP2 of the mouse brain in vivo, C57BL/6 wt, APPfl/fl/APLP2 ko (Mallm et al., 2010), and Nex-Cre/APPfl/fl/APLP2 cdko mice were exposed to $6 \mathrm{~h}$ of $20 \%$ or $6 \% \mathrm{O}_{2}$ and transcript levels quantified. While EPO and VEGFA mRNAs were hypoxically induced by 20 -fold and 4 -fold, respectively, there was no difference between the three genotypes (data not shown). APP deletion efficiency in the cortex of Nex-Cre/APPfl/fl/APLP2 cdko mice was $\sim 70 \%$ on both mRNA and protein levels (data not shown). Of note, APP expression levels are very high in the brain, and the remaining levels of APP might be sufficient to elicit a normal HIF response, making the results of these mouse models inconclusive.

Despite several in vitro and in vivo studies showing a direct link between $\mathrm{A} \beta$ and toxicity in FAD, the molecular nature of this interplay remains elusive (reviewed by Hardy and Selkoe, 2002). An increasing number of reports provide evidence for nonphysiological metal accumulation in the brains of patients with neurodegenerative diseases, such as AD or PD (Barnham and Bush, 2008). Iron and other transition metals can interact with $\mathrm{A} \beta$, leading to increased $\mathrm{A} \beta$ deposition and to neuronal death through oxidative damage (Smith et al., 1997). A novel 
class of drugs target the abnormal metal accumulation, thereby reducing $A \beta$ deposition and oxidative stress in the brain (Cuajungco et al., 2000; Doraiswamy and Finefrock, 2004). Recently, M30 (5-(N-methyl-N-propargyaminomethyl)-8hydroxyquinoline) and HLA20 (5-[4-propargylpiperazin-1ylmethyl]-8-hydroxyquinoline), two novel iron chelating drugs have been evaluated as therapeutic agents in $\mathrm{AD}$ (Zheng et al., 2005). Of note, iron chelators are well known as PHD-inhibiting and HIF-activating compounds (Wang and Semenza, 1993; Wanner et al., 2000; Linden et al., 2003). In particular, M30 has been shown to upregulate HIF and HIF-target genes in cortical neurons (Avramovich-Tirosh et al., 2010). This suggests that HIF activation in the brain might be beneficial for patients suffering from $\mathrm{AD}$ and cognitive dysfunction, and that mechanisms impeding HIF activation might be involved in the pathogenesis of the disease. Indeed, the classical HIF-target genes EPO and $V E G F A$ have been shown to improve cognitive function in mouse models when activated in the brain (Plaschke et al., 2008; Sargin et al., 2011). However, additional studies will be required to investigate whether HIF- $1 \alpha$ can rescue age-dependent neurodegeneration in PSEN1/2 cdko mice. On the other hand, it has been suggested that hypoperfusion/hypoxia may mediate AD progression (Ogunshola and Antoniou, 2009). Of note, a recent report showed elevated expression of HIF- $1 \alpha$ in the brain microvasculature of an AD mouse model (Grammas et al., 2011). Furthermore, hypoxia has been shown to increase the expression of BACE1 (Sun et al., 2006; Zhang et al., 2007) and as a consequence the production of A $\beta$ (Kalaria et al., 1993; Webster et al., 2002; Li et al., 2009). In line with these data, we found lower BACE1 expression in the brain of PSEN1/2 cdko mice. This suggests that decreased $\mathrm{A} \beta$ production after PSEN $1 / 2$ ablation might partially be mediated by HIF and BACE1. In conclusion, HIF-1 activation might exert temporally and spatially diverse functions during the progression of $\mathrm{AD}$.

Intriguingly, PSEN1/2-deficient MEFs that were reconstituted with mutations originally identified in $\mathrm{AD}$ patients displayed a differential response to hypoxia. Although the most severe $\gamma$-secretase loss-of-function mutations $(\Delta \mathrm{E} 9, \mathrm{~L} 166 \mathrm{P})$ did not rescue HIF transcriptional activity, the other mutations (A246E, G384A, N141I) showed an intermediate hypoxic response, confirming the importance of $\gamma$-secretase enzymatic activity for HIF regulation. Extensive analysis of $\gamma$-secretase activity in the different PSEN clinical mutations revealed decreased AICD levels in all mutations with the highest reduction in the L166 mutant (Bentahir et al., 2006; Chavez-Gutierrez et al., 2012). Taking into consideration that FAD is a multifactorial progressive neurodegenerative disease, these results suggest that HIF- $1 \alpha$ protein levels and HIF transcriptional activity in the brain of $\mathrm{AD}$ patients deserve more clinical attention.

\section{References}

Avramovich-Tirosh Y, Bar-Am O, Amit T, Youdim MB, Weinreb O (2010) Up-regulation of hypoxia-inducible factor (HIF)- $1 \alpha$ and HIF-target genes in cortical neurons by the novel multifunctional iron chelator antiAlzheimer drug, M30. Curr Alzheimer Res 7:300-306. CrossRef Medline

Baek SH, Ohgi KA, Rose DW, Koo EH, Glass CK, Rosenfeld MG (2002) Exchange of N-CoR corepressor and Tip60 coactivator complexes links gene expression by NF- $\kappa \mathrm{B}$ and $\beta$-amyloid precursor protein. Cell 110:55-67. CrossRef Medline

Baker NA (1975) A galvanic cell suitable for monitoring cortical oxygen in man. Med Biol Eng 13:443-449. CrossRef Medline

Barnham KJ, Bush AI (2008) Metals in Alzheimer's and Parkinson's diseases. Curr Opin Chem Biol 12:222-228. CrossRef Medline

Barth S, Nesper J, Hasgall PA, Wirthner R, Nytko KJ, Edlich F, Katschinski DM, Stiehl DP, Wenger RH, Camenisch G (2007) The peptidyl prolyl cis/trans isomerase FKBP38 determines hypoxia-inducible transcription factor prolyl-4-hydroxylase PHD2 protein stability. Mol Cell Biol 27: 3758-3768. CrossRef Medline

Barth S, Edlich F, Berchner-Pfannschmidt U, Gneuss S, Jahreis G, Hasgall PA, Fandrey J, Wenger RH, Camenisch G (2009) Hypoxia-inducible factor prolyl-4-hydroxylase PHD2 protein abundance depends on integral membrane anchoring of FKBP38. J Biol Chem 284:23046-23058. CrossRef Medline

Bazan NG, Lukiw WJ (2002) Cyclooxygenase-2 and presenilin-1 gene expression induced by interleukin- $1 \beta$ and amyloid $\beta 42$ peptide is potentiated by hypoxia in primary human neural cells. J Biol Chem 277:30359-30367. CrossRef Medline

Bentahir M, Nyabi O, Verhamme J, Tolia A, Horré K, Wiltfang J, Esselmann H, De Strooper B (2006) Presenilin clinical mutations can affect $\gamma$-secretase activity by different mechanisms. J Neurochem 96:732-742. CrossRef Medline

Bruick RK, McKnight SL (2001) A conserved family of prolyl-4hydroxylases that modify HIF. Science 294:1337-1340. CrossRef Medline

Cao X, Südhof TC (2001) A transcriptionally active complex of APP with Fe65 and histone acetyltransferase Tip60. Science 293:115-120. CrossRef Medline

Chávez-Gutierrez L, Bammens L, Benilova I, Vandersteen A, Benurwar M, Borgers M, Lismont S, Zhou L, Van Cleynenbreugel S, Esselmann H, Wiltfang J, Serneels L, Karran E, Gijsen H, Schymkowitz J, Rousseau F, Broersen K, De Strooper B (2012) The mechanism of $\gamma$-secretase dysfunction in familial Alzheimer disease. EMBO J 31:2261-2274. CrossRef Medline

Cuajungco MP, Fagét KY, Huang X, Tanzi RE, Bush AI (2000) Metal chelation as a potential therapy for Alzheimer's disease. Ann N Y Acad Sci 920:292-304. Medline

Cui JG, Fraser PE, St George-Hyslop P, Westaway D, Lukiw WJ (2004) Potential roles for presenilin-1 in oxygen sensing and in glial-specific gene expression. Neuroreport 15:2025-2028. CrossRef Medline

De Gasperi R, Sosa MA, Dracheva S, Elder GA (2010) Presenilin-1 regulates induction of hypoxia inducible factor- $1 \alpha$ : altered activation by a mutation associated with familial Alzheimer's disease. Mol Neurodegener 5:38. CrossRef Medline

De Strooper B, Saftig P, Craessaerts K, Vanderstichele H, Guhde G, Annaert W, Von Figura K, Van Leuven F (1998) Deficiency of presenilin-1 inhibits the normal cleavage of amyloid precursor protein. Nature 391:387390. CrossRef Medline

De Strooper B, Annaert W, Cupers P, Saftig P, Craessaerts K, Mumm JS, Schroeter EH, Schrijvers V, Wolfe MS, Ray WJ, Goate A, Kopan R (1999) A presenilin-1-dependent $\gamma$-secretase-like protease mediates release of Notch intracellular domain. Nature 398:518-522. CrossRef Medline

Doraiswamy PM, Finefrock AE (2004) Metals in our minds: therapeutic implications for neurodegenerative disorders. Lancet Neurol 3:431-434. CrossRef Medline

Edlich F, Weiwad M, Erdmann F, Fanghänel J, Jarczowski F, Rahfeld JU, Fischer G (2005) Bcl-2 regulator FKBP38 is activated by $\mathrm{Ca}^{2+} /$ calmodulin. EMBO J 24:2688-2699. CrossRef Medline

Ginouvès A, Ilc K, Macías N, Pouysségur J, Berra E (2008) PHDs overactivation during chronic hypoxia "desensitizes" HIFa and protects cells from necrosis. Proc Natl Acad Sci U S A 105:4745-4750. CrossRef Medline

Goodger ZV, Rajendran L, Trutzel A, Kohli BM, Nitsch RM, Konietzko U (2009) Nuclear signaling by the APP intracellular domain occurs predominantly through the amyloidogenic processing pathway. J Cell Sci 122:3703-3714. CrossRef Medline

Grammas P, Tripathy D, Sanchez A, Yin X, Luo J (2011) Brain microvasculature and hypoxia-related proteins in Alzheimer's disease. Int J Clin Exp Pathol 4:616-627. Medline

Gustafsson MV, Zheng X, Pereira T, Gradin K, Jin S, Lundkvist J, Ruas JL, Poellinger L, Lendahl U, Bondesson M (2005) Hypoxia requires notch signaling to maintain the undifferentiated cell state. Dev Cell 9:617-628. CrossRef Medline

Hardy J, Selkoe DJ (2002) The amyloid hypothesis of Alzheimer's disease: progress and problems on the road to therapeutics. Science 297: 353-356. CrossRef Medline

Heber S, Herms J, Gajic V, Hainfellner J, Aguzzi A, Rülicke T, von Kretzschmar H, von Koch C, Sisodia S, Tremml P, Lipp HP, Wolfer DP, Müller U (2000) Mice with combined gene knock-outs reveal essential and par- 
tially redundant functions of amyloid precursor protein family members. J Neurosci 20:7951-7963. Medline

Henze AT, Riedel J, Diem T, Wenner J, Flamme I, Pouyssegur J, Plate KH, Acker T (2010) Prolyl hydroxylases 2 and 3 act in gliomas as protective negative feedback regulators of hypoxia-inducible factors. Cancer Res 70:357-366. CrossRef Medline

Herreman A, Hartmann D, Annaert W, Saftig P, Craessaerts K, Serneels L, Umans L, Schrijvers V, Checler F, Vanderstichele H, Baekelandt V, Dressel R, Cupers P, Huylebroeck D, Zwijsen A, Van Leuven F, De Strooper B (1999) Presenilin 2 deficiency causes a mild pulmonary phenotype and no changes in amyloid precursor protein processing but enhances the embryonic lethal phenotype of presenilin 1 deficiency. Proc Natl Acad Sci U S A 96:11872-11877. CrossRef Medline

Herreman A, Van Gassen G, Bentahir M, Nyabi O, Craessaerts K, Mueller U, Annaert W, De Strooper B (2003) $\gamma$-Secretase activity requires the presenilin-dependent trafficking of nicastrin through the Golgi apparatus but not its complex glycosylation. J Cell Sci 116:1127-1136. CrossRef Medline

Kaelin WG Jr, Ratcliffe PJ (2008) Oxygen sensing by metazoans: the central role of the HIF hydroxylase pathway. Mol Cell 30:393-402. CrossRef Medline

Kalaria RN, Bhatti SU, Palatinsky EA, Pennington DH, Shelton ER, Chan HW, Perry G, Lust WD (1993) Accumulation of the $\beta$ amyloid precursor protein at sites of ischemic injury in rat brain. Neuroreport 4:211-214. CrossRef Medline

Kim HS, Kim EM, Lee JP, Park CH, Kim S, Seo JH, Chang KA, Yu E, Jeong SJ, Chong YH, Suh YH (2003) C-terminal fragments of amyloid precursor protein exert neurotoxicity by inducing glycogen synthase kinase- $3 \beta$ expression. FASEB J 17:1951-1953. CrossRef Medline

Lando D, Peet DJ, Gorman JJ, Whelan DA, Whitelaw ML, Bruick RK (2002) FIH-1 is an asparaginyl hydroxylase enzyme that regulates the transcriptional activity of hypoxia-inducible factor. Genes Dev 16:1466-1471. CrossRef Medline

Lee JH, Suk J, Park J, Kim SB, Kwak SS, Kim JW, Lee CH, Byun B, Ahn JK, Joe CO (2009) Notch signal activates hypoxia pathway through HES1dependent SRC/signal transducers and activators of transcription 3 pathway. Mol Cancer Res 7:1663-1671. CrossRef Medline

Le Moan N, Houslay DM, Christian F, Houslay MD, Akassoglou K (2011) Oxygen-dependent cleavage of the p75 neurotrophin receptor triggers stabilization of HIF-1 $\alpha$. Mol Cell 44:476-490. CrossRef Medline

Li L, Zhang X, Yang D, Luo G, Chen S, Le W (2009) Hypoxia increases Ab generation by altering $\beta$ - and $\gamma$-cleavage of APP. Neurobiol Aging 30: 1091-1098. CrossRef Medline

Liauw J, Nguyen V, Huang J, St George-Hyslop P, Rozmahel R (2002) Differential display analysis of presenilin 1-deficient mouse brains. Brain Res Mol Brain Res 109:56-62. CrossRef Medline

Linden T, Katschinski DM, Eckhardt K, Scheid A, Pagel H, Wenger RH (2003) The antimycotic ciclopirox olamine induces HIF- $1 \alpha$ stability, VEGF expression, and angiogenesis. FASEB J 17:761-763. CrossRef Medline

Mahon PC, Hirota K, Semenza GL (2001) FIH-1: a novel protein that interacts with HIF- $1 \alpha$ and VHL to mediate repression of HIF- 1 transcriptional activity. Genes Dev 15:2675-2686. CrossRef Medline

Mallm JP, Tschäpe JA, Hick M, Filippov MA, Müller UC (2010) Generation of conditional null alleles for APP and APLP2. Genesis 48:200-206. Medline

Martin F, Linden T, Katschinski DM, Oehme F, Flamme I, Mukhopadhyay CK, Eckhardt K, Tröger J, Barth S, Camenisch G, Wenger RH (2005) Copper-dependent activation of hypoxia-inducible factor (HIF)-1: implications for ceruloplasmin regulation. Blood 105:4613-4619. CrossRef Medline

Maxwell PH, Wiesener MS, Chang GW, Clifford SC, Vaux EC, Cockman ME, Wykoff CC, Pugh CW, Maher ER, Ratcliffe PJ (1999) The tumour suppressor protein VHL targets hypoxia-inducible factors for oxygendependent proteolysis. Nature 399:271-275. CrossRef Medline

Nakayama K, Frew IJ, Hagensen M, Skals M, Habelhah H, Bhoumik A, Kadoya $\mathrm{T}$, Erdjument-Bromage H, Tempst P, Frappell PB, Bowtell DD, Ronai Z (2004) Siah2 regulates stability of prolyl-hydroxylases, controls HIF $1 \alpha$ abundance, and modulates physiological responses to hypoxia. Cell 117:941-952. CrossRef Medline

Ogunshola OO, Antoniou X (2009) Contribution of hypoxia to Alzheimer's disease: is HIF- $1 \alpha$ a mediator of neurodegeneration? Cell Mol Life Sci 66:3555-3563. CrossRef Medline

Parks AL, Curtis D (2007) Presenilin diversifies its portfolio. Trends Genet 23:140-150. CrossRef Medline

Peers C, Dallas ML, Boycott HE, Scragg JL, Pearson HA, Boyle JP (2009) Hypoxia and neurodegeneration. Ann N Y Acad Sci 1177:169-177. CrossRef Medline

Plaschke K, Staub J, Ernst E, Marti HH (2008) VEGF overexpression improves mice cognitive abilities after unilateral common carotid artery occlusion. Exp Neurol 214:285-292. CrossRef Medline

Rozmahel R, Mount HT, Chen F, Nguyen V, Huang J, Erdebil S, Liauw J, Yu G, Hasegawa H, Gu Y, Song YQ, Schmidt SD, Nixon RA, Mathews PM, Bergeron C, Fraser P, Westaway D, St George-Hyslop P (2002) Alleles at the Nicastrin locus modify presenilin 1-deficiency phenotype. Proc Natl Acad Sci U S A 99:14452-14457. CrossRef Medline

Sargin D, El-Kordi A, Agarwal A, Müller M, Wojcik SM, Hassouna I, Sperling S, Nave KA, Ehrenreich H (2011) Expression of constitutively active erythropoietin receptor in pyramidal neurons of cortex and hippocampus boosts higher cognitive functions in mice. BMC Biol 9:27. CrossRef Medline

Saura CA, Choi SY, Beglopoulos V, Malkani S, Zhang D, Shankaranarayana Rao BS, Chattarji S, Kelleher RJ 3rd, Kandel ER, Duff K, Kirkwood A, Shen J (2004) Loss of presenilin function causes impairments of memory and synaptic plasticity followed by age-dependent neurodegeneration. Neuron 42:23-36. CrossRef Medline

Schofield CJ, Ratcliffe PJ (2004) Oxygen sensing by HIF hydroxylases. Nat Rev Mol Cell Biol 5:343-354. CrossRef Medline

Semenza GL (2007) Hypoxia-inducible factor 1 (HIF-1) pathway. Sci STKE 2007:cm8. CrossRef Medline

Shen J, Kelleher RJ 3rd (2007) The presenilin hypothesis of Alzheimer's disease: evidence for a loss-of-function pathogenic mechanism. Proc Natl Acad Sci U S A 104:403-409. CrossRef Medline

Sherrington R, Rogaev EI, Liang Y, Rogaeva EA, Levesque G, Ikeda M, Chi H, Lin C, Li G, Holman K, et al. (1995) Cloning of a gene bearing missense mutations in early-onset familial Alzheimer's disease. Nature 375:754760. CrossRef Medline

Smith MA, Harris PL, Sayre LM, Perry G (1997) Iron accumulation in Alzheimer disease is a source of redox-generated free radicals. Proc Natl Acad Sci U S A 94:9866-9868. CrossRef Medline

Stiehl DP, Wirthner R, Köditz J, Spielmann P, Camenisch G, Wenger RH (2006) Increased prolyl 4-hydroxylase domain proteins compensate for decreased oxygen levels: evidence for an autoregulatory oxygen-sensing system. J Biol Chem 281:23482-23491. CrossRef Medline

Sun X, He G, Qing H, Zhou W, Dobie F, Cai F, Staufenbiel M, Huang LE, Song W (2006) Hypoxia facilitates Alzheimer's disease pathogenesis by up-regulating BACE1 gene expression. Proc Natl Acad Sci U S A 103: 18727-18732. CrossRef Medline

von Koch CS, Zheng H, Chen H, Trumbauer M, Thinakaran G, van der Ploeg LH, Price DL, Sisodia SS (1997) Generation of APLP2 KO mice and early postnatal lethality in APLP2/APP double KO mice. Neurobiol Aging 18:661-669. CrossRef Medline

von Rotz RC, Kohli BM, Bosset J, Meier M, Suzuki T, Nitsch RM, Konietzko U (2004) The APP intracellular domain forms nuclear multiprotein complexes and regulates the transcription of its own precursor. J Cell Sci 117:4435-4448. CrossRef Medline

Wakabayashi T, De Strooper B (2008) Presenilins: members of the $\gamma$-secretase quartets, but part-time soloists too. Physiology (Bethesda) 23:194-204. CrossRef Medline

Wang GL, Semenza GL (1993) Desferrioxamine induces erythropoietin gene expression and hypoxia-inducible factor 1 DNA-binding activity: implications for models of hypoxia signal transduction. Blood 82:36103615. Medline

Wang HQ, Nakaya Y, Du Z, Yamane T, Shirane M, Kudo T, Takeda M, Takebayashi K, Noda Y, Nakayama KI, Nishimura M (2005) Interaction of presenilins with FKBP38 promotes apoptosis by reducing mitochondrial Bcl-2. Hum Mol Genet 14:1889-1902. CrossRef Medline

Wanner RM, Spielmann P, Stroka DM, Camenisch G, Camenisch I, Scheid A, Houck DR, Bauer C, Gassmann M, Wenger RH (2000) Epolones induce erythropoietin expression via hypoxia-inducible factor-1 $\alpha$ activation. Blood 96:1558-1565. Medline

Webster NJ, Green KN, Peers C, Vaughan PF (2002) Altered processing of 
amyloid precursor protein in the human neuroblastoma SH-SY5Y by chronic hypoxia. J Neurochem 83:1262-1271. CrossRef Medline

Wenger RH, Rolfs A, Kvietikova I, Spielmann P, Zimmermann DR, Gassmann M (1997) The mouse gene for hypoxia-inducible factor- $1 \alpha$ genomic organization, expression and characterization of an alternative first exon and 5' flanking sequence. Eur J Biochem 246:155-165. CrossRef Medline

Wenger RH, Rolfs A, Spielmann P, Zimmermann DR, Gassmann M (1998) Mouse hypoxia-inducible factor- $1 \alpha$ is encoded by two different mRNA isoforms: expression from a tissue-specific and a housekeeping-type promoter. Blood 91:3471-3480. Medline

Wenger RH, Stiehl DP, Camenisch G (2005) Integration of oxygen signaling at the consensus HRE. Sci STKE 2005:re12. CrossRef Medline

Wiley JC, Smith EA, Hudson MP, Ladiges WC, Bothwell M (2007) Fe65 stimulates proteolytic liberation of the $\beta$-amyloid precursor protein intracellular domain. J Biol Chem 282:33313-33325. CrossRef Medline

Wolfe MS, Xia W, Ostaszewski BL, Diehl TS, Kimberly WT, Selkoe DJ (1999) Two transmembrane aspartates in presenilin-1 required for presenilin endoproteolysis and $\gamma$-secretase activity. Nature 398:513-517. CrossRef Medline

Wollenick K, Hu J, Kristiansen G, Schraml P, Rehrauer H, BerchnerPfannschmidt U, Fandrey J, Wenger RH, Stiehl DP (2012) Synthetic transactivation screening reveals ETV4 as broad coactivator of hypoxiainducible factor signaling. Nucleic Acids Res 40:1928-1943. Medline

Yang G, Gong YD, Gong K, Jiang WL, Kwon E, Wang P, Zheng H, Zhang XF, Gan WB, Zhao NM (2005) Reduced synaptic vesicle density and active zone size in mice lacking amyloid precursor protein (APP) and APP-like protein 2. Neurosci Lett 384:66-71. CrossRef Medline

Zhang X, Le W (2010) Pathological role of hypoxia in Alzheimer's disease. Exp Neurol 223:299-303. CrossRef Medline

Zhang X, Zhou K, Wang R, Cui J, Lipton SA, Liao FF, Xu H, Zhang YW (2007) Hypoxia-inducible factor $1 \alpha$ (HIF- $1 \alpha)$-mediated hypoxia increases BACE1 expression and $\beta$-amyloid generation. J Biol Chem 282: 10873-10880. CrossRef Medline

Zheng H, Jiang M, Trumbauer ME, Sirinathsinghji DJ, Hopkins R, Smith DW, Heavens RP, Dawson GR, Boyce S, Conner MW, Stevens KA, Slunt HH, Sisoda SS, Chen HY, Van der Ploeg LH (1995) $\beta$-Amyloid precursor protein-deficient mice show reactive gliosis and decreased locomotor activity. Cell 81:525-531. CrossRef Medline

Zheng H, Gal S, Weiner LM, Bar-Am O, Warshawsky A, Fridkin M, Youdim MB (2005) Novel multifunctional neuroprotective iron chelatormonoamine oxidase inhibitor drugs for neurodegenerative diseases: in vitro studies on antioxidant activity, prevention of lipid peroxide formation and monoamine oxidase inhibition. J Neurochem 95:68-78. CrossRef Medline 